\title{
Assessment of Physico-chemical Characteristics of Tomato (Solanum lycopersicum) Stored under Diffusion Channel System
}

\author{
Palani Kandasamy*
}

Dept. of Agricultural Engineering, Institute of Agriculture, Visva-Bharati University, Sriniketan, West Bengal (731236), India

\author{
Corresponding Author \\ Palani Kandasamy \\ e-mail: pkandasamy1973@gmail.com
}

\author{
Article History \\ Manuscript No. AR1794 \\ Received in $23^{\text {rd }}$ Jan, 2017 \\ Received in revised form $6^{\text {th }}$ Feb, 2017 \\ Accepted in final form $7^{\text {th }}$ Feb, 2017
}

\begin{abstract}
A study was conducted to extend the shelf-life of tomato by diffusion channel system at the Institute of Agriculture, Visva-Bharati University, Sriniketan, West Bengal during 2010-12. Diffusion channel length 60, 120, 180 and $240 \mathrm{~mm}$ and diameter 3, 6, 9 and $12 \mathrm{~mm}$ were tested. The storage chambers of two liters capacity made of polyethylene tetrachloride were used. Tomato samples of $800 \pm 20 \mathrm{~g}$ at breaker stage were taken in each chamber and stored at 10, 20 and $30^{\circ} \mathrm{C}$. Quality characteristics such as physiological loss in weight (PLW), visual quality index (VQI), firmness, total soluble solids (TSS), titratable acidity, total sugars, ascorbic acid, lycopene and colour change ( $\triangle \mathrm{E}$ ) were tested before and after storage to distinguish the relative changes. The stored tomato attained market acceptability after 40, 32 and 23 days at 10 , 20 and $30^{\circ} \mathrm{C}$ respectively under diffusion channel system. Minimum PLW of 3.37-3.74\%, highest VQI number of 6.9-7, maximum firmness of $90-94 \mathrm{~N}$, titratable acidity as high as $0.46-0.48 \%$, ascorbic acid content as low as $22.97 \mathrm{mg} 100 \mathrm{~g}^{-1}$, lycopene formation as low as $2.58-2.62$

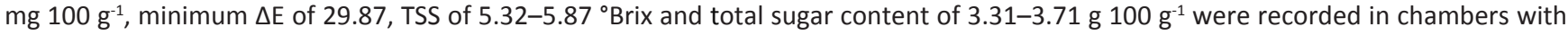
diffusion channel length $180 \mathrm{~mm}$ and diameter $9 \mathrm{~mm}$ at 10 and $20^{\circ} \mathrm{C}$. Firmness, acidity and ascorbic acid were found significant ( $p \leq 0.05$ ) by temperature, channel length and diameter. Total sugars and lycopene content had a significant difference with temperature and channel diameter. Temperature had a significant effect on TSS but length and diameter of channel had no significant effect.
\end{abstract}

Keywords: Tomato, diffusion channel, controlled atmosphere storage, physico-chemical characteristics

\section{Introduction}

Tomato (Solanum lycopersicum) is a wonderful vegetable embraced incredible health promoting properties such as vitamins, minerals, carbohydrates, carotenoids, fiber, fat and protein. It has good source of lycopene that has been proved in decreased risk of cardiovascular disease and cancer including breast and prostate cancer (Agarwal and Rao, 2000). Since, it is highly perishable in nature encounters several problems in its transportation, storage and marketing. It has been reported that the loss of $20-50 \%$ between harvesting and consumption of fresh tomato in tropical countries (Pila et al., 2010). Therefore, an increase in postharvest life is really desirable to reduce losses during supply chain. Major physiological activity in the postharvest life of a produce is respiration. Respiration is considered to be a key process which brings physiological disorders such as ripening, senescence, decay, degradation of chlorophyll and subsequently deterioration in the normal course of time. Respiration involving the consumption of oxygen $\left(\mathrm{O}_{2}\right)$ for oxidative break-down of organic components into simple molecules such as carbon dioxide $\left(\mathrm{CO}_{2}\right)$, water, with concurrent release of energy and other intermediates which can be used by the cell for synthetic reactions (Kader et al., 1989). The rate of physiological disorders can be slowed in low temperature and modified atmospheric condition. Modified atmosphere can be achieved by the natural interplay between respiration rate of the produce and transfer of gases through the storage that lead to an atmosphere richer in $\mathrm{CO}_{2}$ and poorer in $\mathrm{O}_{2}$. This atmosphere can potentially reduce the rate of respiration of the produce (Zagory and Kader, 1988; Mahajan and Goswami, 2001; Fonseca et al., 2002). Several researchers (Klieber et al., 1996; Sozzi et al., 1999; Akbudak and Eris, 2004; Kudachikar et al., 2011; Ramayya et al., 2012; Majidi et al., 2014; Vunnam et al., 2014) have been conducted experiments on enhancing the shelf life of various fruits by altering the gas compositions. Polymeric films, used as packaging materials for modified atmosphere packaging (MAP) are limited to gas permeability. In general, the fresh produce in MAP consumes $\mathrm{O}_{2}$ and liberates $\mathrm{CO}_{2}$ results absence of $\mathrm{O}_{2}$ that leads to anaerobic respiration. It accelerates senescence, off-flavour and spoilage of produce due to fermentation (Kader et al., 1989). The limitations associated with polymeric films could be solved by use of perforations which are related to diffusion channel.

Diffusion channel system works based on the principle of 
Fick's first law of gas diffusion. It states that the gas flux moves from a region of higher concentration to a region of lower concentration, with a magnitude that is proportional to the concentration gradient. Diffusion channel is a hollow tube fitted in an airtight storage chamber in which fresh produce is stored. Diffusion of gases takes place through the tube due to the concentration gradient between inside and outside the storage chamber. This creates a modified atmosphere inside the chamber which is beneficial for the storage (Baugerod, 1980). As a result of respiratory activity of stored produce, concentration of $\mathrm{O}_{2}$ will be decreased and $\mathrm{CO}_{2}$ increased. This creates a concentration gradient between inside and outside the chamber. Due to the concentration gradient, $\mathrm{O}_{2}$ diffuses from outside to inside and $\mathrm{CO}_{2}$ diffuses from inside to outside the chamber through the tube. Thereby a steadystate level of gases is maintained that depends on mass of the produce, rate of respiration and rate of diffusion of the gases. The rate of diffusion of gases is dependent on the length and cross-sectional area of the channel/tube (Ratti et al., 1998; Stewart et al., 2005). The gas composition in the storage chambers could easily be altered by varying the dimensions of the diffusion channels. Diffusion channel is used due to its extreme structural simplicity, which provides great flexibility in the design of storage chamber and the materials used are considerably less expensive. The quality of stored produce is well maintained. Keeping in view of the above perspectives, the investigation on enhancing the shelf life of tomato under diffusion channel system has been undertaken. Evaluation of physico-chemical characteristics of tomato stored under diffusion channel system, a part of this study have been reported in this paper.

\section{Materials and Methods}

\subsection{Sample preparation}

The investigation on enhancing the shelf life of tomato using diffusion channel system was carried out at the Institute of Agriculture, Visva-Bharati University, Sriniketan, West Bengal (India) during 2010-12. The popular tomato variety namely Roma in the West Bengal was selected. The matured tomatoes at breaker stage of ripeness and uniform size were procured from a farmer field near Visva-Bharati University. Breaker stage is a definite break in color from green to tannish-yellow, green with orange locular tissue and pink on not more than $10 \%$ of the surface (Sammi and Masud, 2007). The harvested tomatoes were graded manually and washed in chlorinated water concentration of $100 \mathrm{ppm}$ to remove adhering dirt on their surface.

\subsection{Experimental setup}

Diffusion channel made of fiber glass comprising inner diameter of 3, 6, 9 and $12 \mathrm{~mm}$ and length of 60,120, 180 and $240 \mathrm{~mm}$ were selected based on the information available in the previous study (Ratti et al., 1998; Stewart et al., 2005). The storage temperatures viz., 10,20 and $30^{\circ} \mathrm{C}$ were selected. The storage chambers of two liters capacity made of polyethylene tetrachloride (PET) were used for conducting the experiments.
The experimental setup (Figure 1) was fabricated in such a way that four holes were provided on the lid. A silicon septum was fitted in the first hole to facilitate the withdrawal of gas sample from the chamber for analysis. Brass nipples with rubber gaskets were connected in second and third holes and tightened with nuts. A rubber tube length of $200 \mathrm{~mm}$ were connected to these nipples and closed by pinch clips after purging gas. In the fourth hole, a conical shape hallow rubber cork was fitted. The diffusion channel required size was rigidly fixed in the rubber cork. The joints were crammed by melted paraffin wax to secure air tightness. The absence of air bubble ensured the air tightness of diffusion chambers. Tomato samples of $800 \pm 20 \mathrm{~g}$ were taken in each storage chamber and kept in selected temperature. The temperature was maintained throughout the storage period.

\subsection{Bio-chemical analysis}

To distinguish the relative changes in quality during storage under diffusion channel system, the bio-chemical characteristics such as total soluble solids (TSS), titratable

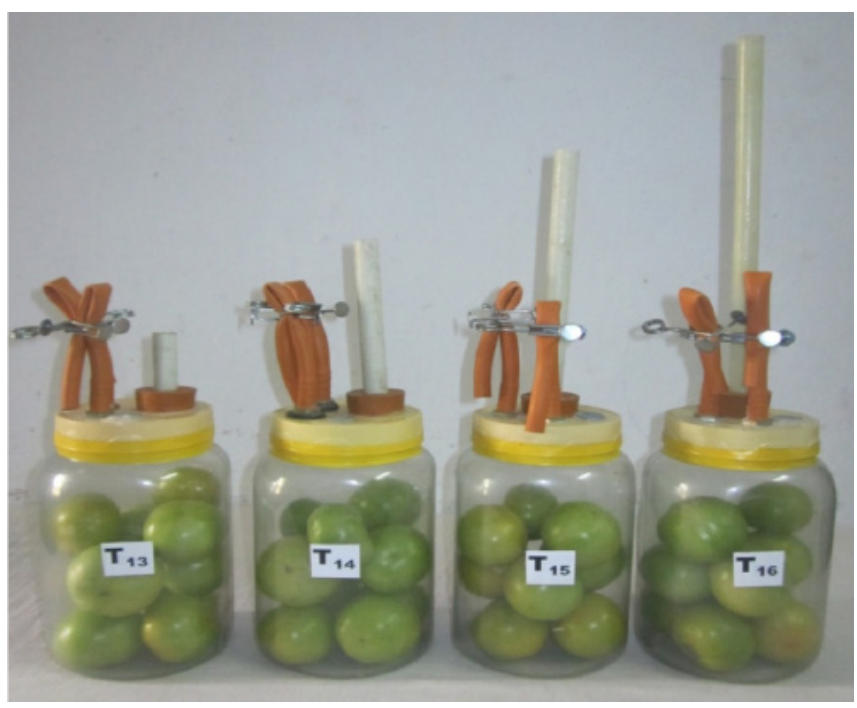

Figure 1: Experimental setup (diffusion channel system)

acidity, total sugars, ascorbic acid and lycopene were determined in the laboratory after storage and before storage at breaker stage. The bio-chemical characteristics of freshly harvested ripe tomato also were determined to compare with the stored tomato. Total soluble solids (TSS) can be used for estimation of concentration of sugar and it can be expressed in degree Brix. TSS in degree Brix was directly measured using Abbe hand refractometer (Model NI; ATAGO, Japan) by placing a drop of supernatant on the prism of refractometer. Total sugars, titratable acidity, ascorbic acid and lycopene were determined as per the methods described by Ranganna (1986).

\subsection{Texture analysis}

Firmness of fruit referred to as the degree of softening. It was measured in terms of force (Newton) required to penetrate into the fruit through skin. The fruit penetrometer (Model 
FT 327) fitted with a cylindrical plunger probe of $11 \mathrm{~mm}$ diameter made of stainless steel was used for measurement of firmness. Average of two forces at two diametrically opposite positions on the circumference of each tomato was taken. The penetrating force depends on the softness of fruit tissues and it is directly proportional to the firmness. For safety point of view, the penetrating force should be more (Sozzi et al., 1999).

\subsection{Surface colour analysis}

The surface colour of the tomato was measured using Minolta colorimeter (Minolta Co. Ltd., Japan) under hunter lab system with observation angle of $45^{\circ}$ (Helga et al., 1999). It provides a reading in terms of $\mathrm{L}^{*}, \mathrm{a}^{*}$, and $\mathrm{b}^{*}$ which describes chromaticity. $\mathrm{L}^{*}$ denotes measurement of luminance (lightness) on a scale ranging from zero (black) to 100 (white); a* denotes degree of greenness when negative and degree of redness when positive; $b^{*}$ denotes degree of blueness when negative and degree of yellowness when positive. These three values were recorded at three points on the circumference of the whole tomato fruits and the colour was computed by average of three measurements. The colour measurements were made on tomato before and after storage on three samples from each treatment. Reference colour values for the fresh samples, before storage $\left(L_{f}^{*}, a_{f}{ }^{*}, b_{f}^{*}\right)$ and colour values from stored samples $\left(L_{s}{ }^{*}, a_{s}{ }^{*}, b_{s}{ }^{*}\right)$ were employed in calculating the colour change $(\Delta E)$, as defined by McGuire (1992); Vunnam et al. (2014):

$\Delta \mathrm{E}=\sqrt{\left(L_{f}^{*}-L_{s}^{*}\right) 2+\left(a_{f}^{*}-a_{s}^{*}\right)^{2}+\left(b_{f}^{*}-b_{s}^{*}\right)^{2}}$

Where, $\Delta \mathrm{E}$ is the total change in colour, $\mathrm{L}_{\mathrm{f}}$ is the brightness value of fresh produce before storage, $L_{s}$ is the brightness value of stored produce, $a_{f}$ is the hue value of fresh produce before storage, $a_{s}$ is the hue value of stored produce, $b_{f}$ is the chroma value of fresh produce before storage and $b_{s}$ is the chroma value of stored produce.

\subsection{Visual quality index}

Visual observations were made by a jury of five persons to evaluate the overall market acceptability of the tomato taking into account discoloration, over softening, chilling injuries, decay, rotting, mold growth and shrinkage. Visual quality index (VQI) on 9-point grading scale described by Klieber et al. (1996); Wrzodak and Adamicki (2007) were used. Time, in which the stored tomato attained overall market acceptability, was considered for the end of storage. The storage time of 40 days at $10{ }^{\circ} \mathrm{C}, 32$ days at $20^{\circ} \mathrm{C}$ and 23 days at $10^{\circ} \mathrm{C}$ were confirmed under diffusion channel system. But, the tomato was stored upto 14 days at $10^{\circ} \mathrm{C}, 12$ days at $20^{\circ} \mathrm{C}$ and 7 days at $30{ }^{\circ} \mathrm{C}$ under control.

\subsection{Statistical analysis}

All the quality characteristics were determined for five representative samples in triplicate and the average values were determined. Factorial completely randomized design using AGRESS software package $(p \leq 0.05)$ was applied to analysis the effect of different diffusion channel lengths, diameters and temperatures on quality of tomato.

\section{Results and Discussion}

The biochemical constitutions of tomato at breaker stage and freshly harvested ripe tomato were presented in Table 1. The results obtained on biochemical constitutes were confirmed with the findings reported by Moneruzzaman et al. (2008); Pila et al. (2010).

\subsection{Visual quality index}

Figure 2(a) shows the effect of different diffusion channel diameter, length and temperature on VQI at the end of storage. Highest VQI number (6.91-7) was recorded in chambers with diffusion channel diameter 9 and $12 \mathrm{~mm}$ and length 180

Table 1: Physico-chemical characteristics of breaker stage and freshly harvested ripe tomato

\begin{tabular}{lcc}
\hline Parameters & $\begin{array}{c}\text { Breaker stage } \\
\text { tomato }\end{array}$ & $\begin{array}{c}\text { Freshly harvest- } \\
\text { ed ripe tomato }\end{array}$ \\
\hline Firmness (N) & 135.964 & 54.193 \\
Total soluble solids ( ${ }^{\circ}$ Brix) & 4.571 & 6.541 \\
Titratable acidity (\%) & 0.655 & 0.422 \\
Total sugars (g $100 \mathrm{~g}^{-1}$ ) & 2.627 & 4.845 \\
Ascorbic acid $\left({\left.\mathrm{mg} 100 \mathrm{~g}^{-1}\right)}\right.$ & 15.760 & 34.535 \\
Lycopene (mg $100 \mathrm{~g}^{-1}$ ) & 0.947 & 5.215 \\
Colour value & & \\
$\mathrm{L}^{*}$ & 57.452 & 36.822 \\
a* & -1.372 & 26.843 \\
b* & 12.651 & 21.781 \\
$\Delta \mathrm{E}$ & 0.00 & 36.125 \\
\hline
\end{tabular}

Each observation is the average of three replicates

and $240 \mathrm{~mm}$ as compared to other treatments. In control it was 5.42-5.97. The effect of temperature, diameter and length of channel on VQI was found significant at $(p \leq 0.05)$ while interaction effect was not significant. The results were supported by the study made by Wrzodak and Adamicki (2007) for tomato under controlled atmosphere storage.

\subsection{Physiological loss in weight}

Under the diffusion channel system, the PLW was found to be low compared to control. The PLW (\%) was higher at 30 ${ }^{\circ} \mathrm{C}$ followed by $20^{\circ} \mathrm{C}$ and $10^{\circ} \mathrm{C}$ irrespective of the treatments (Figure 2b). The mean PLW was 3.1, 3.68 and 5.11\% at 10, 20 and $30{ }^{\circ} \mathrm{C}$ respectively but $4.11,6.51$ and $9.45 \%$ in control. High mean PLW of 4.41 and $4.05 \%$ was recorded in the chambers equipped with channel diameter $3 \mathrm{~mm}$ and length $60 \mathrm{~mm}$. At the same time, low weight loss of 3.37 to $3.74 \%$ was recorded in the chambers equipped with channel diameter 9 and 12 $\mathrm{mm}$ and length $120 \mathrm{~mm}$. Low $\mathrm{O}_{2}$ in storage chambers turn to decrease the respiration rate thereby delayed physiological changes (Koca et al., 1993). Effect of temperature, diameter and length of diffusion channel on PLW was found statistically 
significant ( $p \leq 0.05)$. The results obtained from this study were in conformation with the results reported by other authors (Kudachikar et al., 2011; Ramayya et al., 2012; Vunnam et al., 2014).

\subsection{Firmness}

Effect of temperature, diameter and length of channel on mean firmness $(\mathrm{N})$ of stored tomato at end of storage period is presented in Figure 2(c). Highest firmness ranges between 89.34 and $94.05 \mathrm{~N}$ was recorded in the chambers equipped with channel diameter 9 and $12 \mathrm{~mm}$ and length 180 and 240 $\mathrm{mm}$. Average firmness of 89.24 and $80.03 \mathrm{~N}$ were recorded at 10 and $30{ }^{\circ} \mathrm{C}$ respectively but it was 57.37 to $68.35 \mathrm{~N}$ in control. More firmness was observed while increasing length
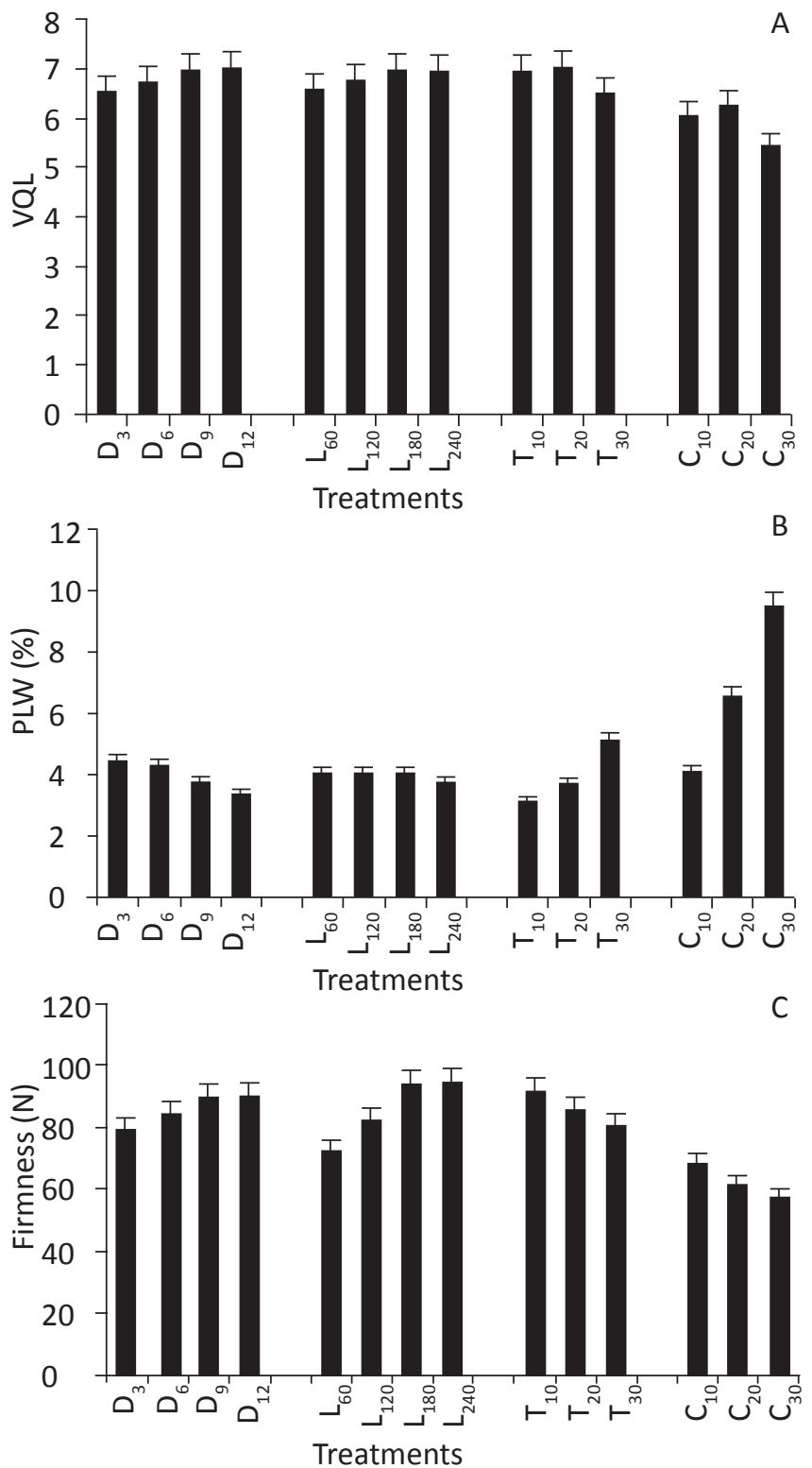

Figure 2: Effect of different treatments on (a) visual quality index (VQI) (b) physiological loss in weight (PLW) and (c) firmness of tomato at the end of storage (Error with $5 \%$ value) and diameter of channel and decreasing in temperature. This may be due to less diffusion of $\mathrm{O}_{2}$ taking place in chambers equipped with higher length of channel. Hence, there is decreased respiration rate and slowdown ripening process. Higher $\mathrm{CO}_{2}$ concentration results in suppression of the degradation of protopectin to soluble pectin thus reducing fruit softening (Klieber et al., 1996). Effect of temperature, diameter and length of channel on the firmness was found to be significant at $(p \leq 0.05)$ but interaction effects were not significant. Thus, the channel diameter of $9 \mathrm{~mm}$ and length of $180 \mathrm{~mm}$ at 10 and $20{ }^{\circ} \mathrm{C}$ was adjudged to be best as it was maximum firmness. The results were consistent with findings of Wrzodak and Adamicki (2007); Kudachikar et al. (2011); Majidi et al. (2014); Vunnam et al. (2014).

\subsection{Total soluble solids}

The TSS was observed in the range of $5.32-5.87^{\circ}$ Brix at the end of storage period irrespective of the treatments, whereas it was 5.3 to $6.4^{\circ} \mathrm{Brix}$ in control (Figure 3a). However, the TSS of $6.54^{\circ}$ Brix was measured in fresh harvested ripe fruits of the same variety (Table 1 ). The reduction in TSS under diffusion channel system may be due to slight conversion of sugars. Statistical analysis showed that the effect of length and diameter of channel on TSS was not significant but temperature had significant variation. However, the results obtained in control were found to be significant $(p \leq 0.05)$. These results were in agreement with results reported by Javanmardi and Kubota 2006; Majidi et al. (2014).

\subsection{Titratable acidity}

The sour taste of tomato is attributed mainly by citric and malic acids. Free amino acids such as glutamic acid play vital role of taste-enhancement. 'Sourness' closely correlates with titratable acidity. Generally, the level of acidity in the fruits decreases during ripening process. At the breaker stage, it was found $0.655 \%$ whereas fresh harvested red ripe $0.422 \%$ (Table 1). In diffusion channel system, the level of titratable acidity increased with increase in the diameter and length of diffusion channel (Figure 3b). When the diameter and length of channel was 9 and $180 \mathrm{~mm}$ respectively, the acidity level was as high as $0.46-0.48 \%$. Beyond this level of diameter and length there was no appreciable change in titratable acidity. It was also observed that the acidity level decreased as temperature increased. This might be due to the rate of respiration that subsides at lower temperature (10 and 20 $\left.{ }^{\circ} \mathrm{C}\right)$ compared to higher temperature $\left(30^{\circ} \mathrm{C}\right)$. Therefore, the conversion of acidity into sugars may be delayed thereby quick ripening was also delayed. At the same time, the acidity level in control was found $0.41-0.42 \%$. The influence of temperature, diameter and length of diffusion channel on titratable acidity was found to be significant $(p \leq 0.05)$ but the interaction effect had no significant influence. The results were supported by results of Majidi et al. (2014); Vunnam et al. 2014.

\subsection{Total sugars}

Degradation of starch during ripening is the causes of production of glucose and fructose that builds sweetness in fruits. The taste of a fruit depends on the total sugar content. 


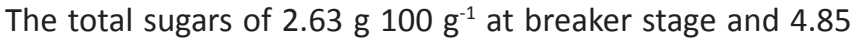
g $100 \mathrm{~g}^{-1}$ at fresh harvested ripe stage were determined (Table 1). One of the main intentions of the study is to delay the degradation of the starch into glucose and fructose. Sammi and Masud (2007) also reported that the total sugars content in green and ripe tomato were 2.86 and $4.99 \mathrm{~g} 100$ $\mathrm{g}^{-1}$ respectively. Total sugar content under diffusion channel

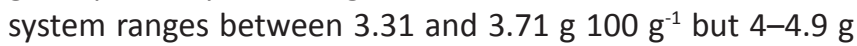
$100 \mathrm{~g}^{-1}$ in control. No appreciable change in total sugars by changing length of channel but decreasing trend was noticed with increasing diameter of the channel (Figure 3c). Moreover, it was observed that the changes in sugar content was significantly less in chambers with diffusion channel of $9 \mathrm{~mm}$ diameter and $180 \mathrm{~mm}$ length. This might be due to low $\mathrm{O}_{2}$ level which controlled the respiration rate thus delaying degradation of starch into sugars (Tasdelen and Bayindirli, 1998). Effect of
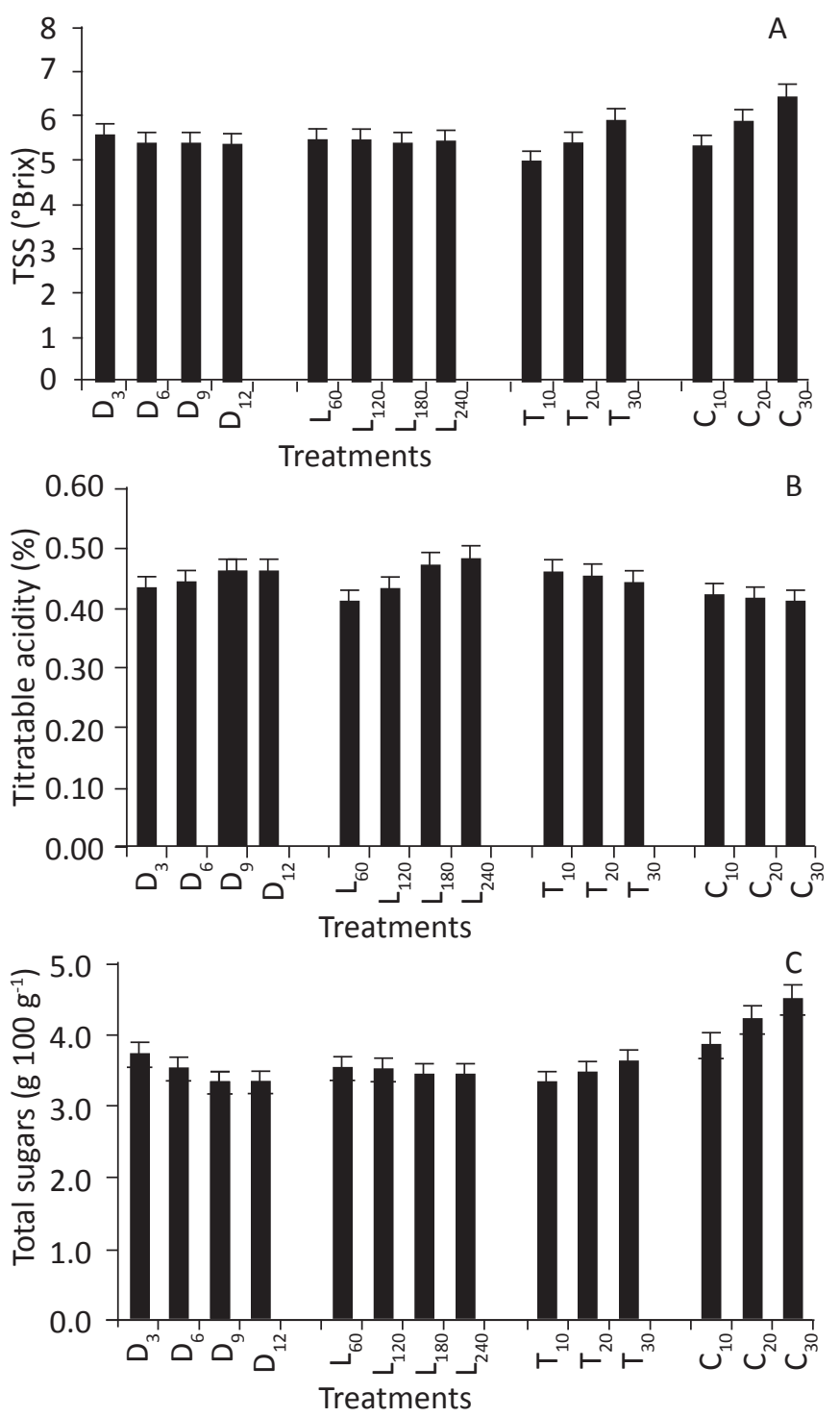

Figure 3: Effect of different treatments on (a) total soluble solids (TSS) (b) titratable acidity and (c) total sugars of tomato at the end of storage (Error with $5 \%$ value) individual treatments such as diameter of the channel and temperature were found significant $(p \leq 0.05)$ statistically but channel length was not significant. However, the interaction effect between these three parameters was not significant. The results were in conformation with the findings reported by Tasdelen and Bayindirli (1998); Kudachikar et al. (2011).

\subsection{Ascorbic acid content}

Ascorbic acid (Vitamin-C) exhibits more at ripened fruits. Ascorbic acid content of 15.76 and $34.54 \mathrm{mg}_{100 \mathrm{~g}^{-1} \text { at }}$ breaker and fresh harvested ripe stage tomato respectively were recorded (Table 1). The effect of different temperature, diameter and length of diffusion channel on ascorbic acid content of tomato at the end of storage is shown in Figure 4(a). The ascorbic acid content was recorded slightly low with increase in diameter and length of channel but no appreciable decrease beyond the channel diameter and length of 9 and 180 $\mathrm{mm}$ respectively. At the same time it increased with increase in the temperature. The level of ascorbic acid was less under diffusion channel system irrespective of the treatments as compared to control. The minimum ascorbic acid content of

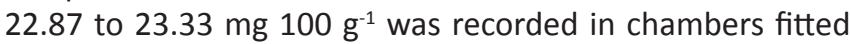
with the channel diameter of 9 and $12 \mathrm{~mm}$, channel length of 180 and $240 \mathrm{~mm}$ at 10 and $20^{\circ} \mathrm{C}$. The control had maximum ascorbic acid of 24.24, 28.47 and $31.17 \mathrm{mg} 100 \mathrm{~g}^{-1}$ at 10, 20 and $30{ }^{\circ} \mathrm{C}$ respectively. This may be due to high $\mathrm{CO}_{2}$ and low $\mathrm{O}_{2}$ reduced the respiration rate, thus hindered the ripening rate, delaying ascorbic acid production. Effect of temperature, diameter and length of the channel were found slightly significant both at $5 \%$ level, whereas the effect of first order and second order interactions were found not significant. The results were in conformation with the results reported by Ramayya et al. (2012).

\subsection{Lycopene content}

Carotenoids, mainly lycopene, are responsible for red colour of tomato. Color changes during ripening are characterized by loss of chlorophyll and rapid accumulation of lycopene. The

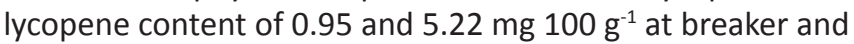
fresh harvested ripe stage respectively was recorded (Table 1). Figure 4(b) shows the effect of temperature, diameter and length of diffusion channel on lycopene content of tomato. The lycopene content significantly decreased when increasing the channel diameter from 3 to $9 \mathrm{~mm}$ and channel length from 60$180 \mathrm{~mm}$ but beyond this level there was no much considerable change. On the other hand, significant increase was observed with increase in temperature. The lycopene ranges between

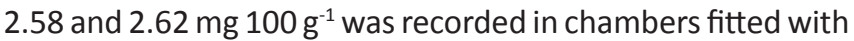
the channel diameter of 9 and $12 \mathrm{~mm}$ and length of 180 and

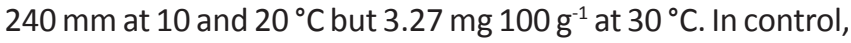
maximum lycopene content of $3.26,3.58$ and $3.85 \mathrm{mg}^{100 \mathrm{~g}^{-1}}$ at 10,20 and $30^{\circ} \mathrm{C}$ respectively were recorded. The lycopene content of tomato stored under diffusion channel system was low as compared to control and fresh red ripe tomato. This may be due to formation of lycopene inhibited by low $\mathrm{O}_{2}$ atmosphere storage under diffusion channel system. The low $\mathrm{O}_{2}$ and temperature prevents the ethylene formation thus 
decreased lycopene production (Helyes et al., 2011). Effect of temperature and diameter of the channel on lycopene was found statistically significant at $5 \%$ level. However, the effect of first order and second order interactions were not significant. These results were consistent with findings of Tasdelen and Bayindirli (1998); Sozzi et al. (1999); Helyes et al. (2011).

\subsection{Colour change}

Appearance is one of the salient features of fruits and vegetables. It may be influenced by several factors of which colour is the most important that directly affects the consumer acceptability. Total change in colour $(\Delta E)$ indicates the deviation in reflection. Initial $\Delta \mathrm{E}$ value for the fresh samples (breaker stage) was recorded as zero and $\Delta \mathrm{E}$ for fresh harvested ripe red tomato 36.13 (Table 1). The effect of different temperature, diameter and length of channel on $\Delta \mathrm{E}$ value is depicted in Figure $4(\mathrm{c})$. The $\Delta \mathrm{E}$ value decreased
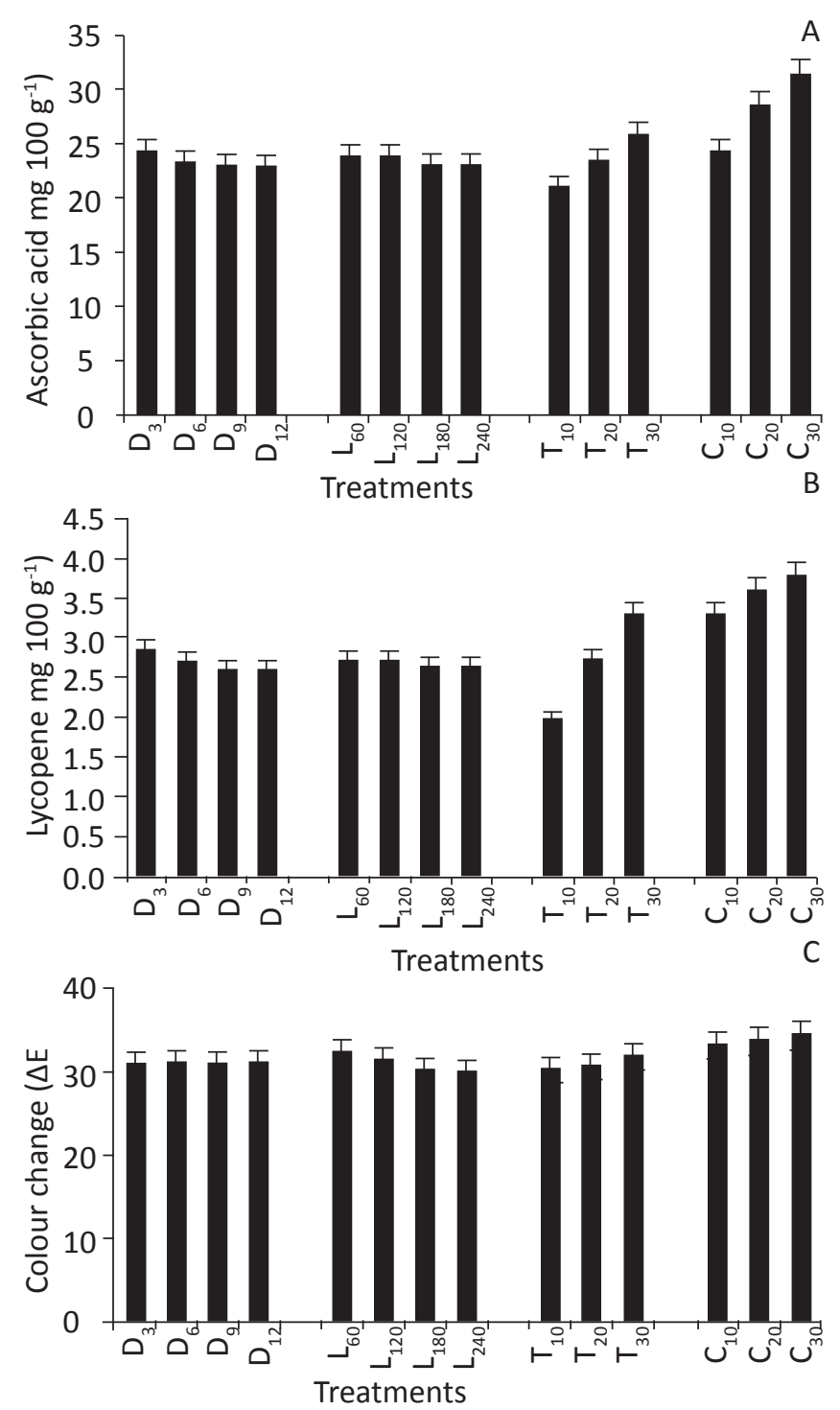

Figure 4: Effect of different treatments on (a) ascorbic acid (b) lycopene and $(c)$ colour change $(\Delta E)$ of tomato at the end of storage (Error with 5\% value) from 32.30 to 29.87 when the channel length increased from $60 \mathrm{~mm}$ to $240 \mathrm{~mm}$. Temperature had a little effect over the $\Delta \mathrm{E}$ value (30.21 to 30.79 ). However, the channel diameter had no much influence over the $\Delta E$ value (30.78 to 31.05$)$. In control, the $\Delta \mathrm{E}$ value ranged between 33.23 and 34.22 that higher than tomato under diffusion channel system. The decrease in $\Delta \mathrm{E}$ value indicates the slower rate of change in colour under diffusion channel system. This may be due to higher $\mathrm{CO}_{2}$ and lower $\mathrm{O}_{2}$ inhibits formation of lycopene that is main constituent of red pigment (Yang et al., 1987). The channel diameter of $9 \mathrm{~mm}$, length of $180 \mathrm{~mm}$ and temperature of 10 and $20^{\circ} \mathrm{C}$ delayed change in colour $(\Delta \mathrm{E})$ compared to other treatments. The temperature and channel length had a significant difference $(p \leq 0.05)$ but channel diameter had no significant effect on colour change. The effects of first order, second order interactions and control were also not significant. The results of colour change $(\Delta \mathrm{E})$ were conformed to the findings reported by Vunnam et al. (2014).

\section{Conclusion}

The physico-chemical characteristics indicated that the tomato can be stored upto 40,32 and 23 days at 10,20 and $30{ }^{\circ} \mathrm{C}$ respectively under diffusion channel system (length:180 mm and diameter: $9 \mathrm{~mm}$ ). But under control, 14, 12 and 7 days at 10,20 and $30{ }^{\circ} \mathrm{C}$ respectively. Therefore, shelf life of tomato could be increased approximately 2-3 times when compared to control. Moreover, tomato stored under this system had better texture, harvest-fresh appearance, retained nutritional values and marketability conditions.

\section{References}

Agarwal, S., Rao, A.V., 2000. Tomato lycopene and its role in human health and chronic diseases. Canadian Medical Association Journal 163(6), 739-744.

Akbudak, B., Eris, A., 2004. Physical and chemical changes in peaches and nectarines during the modified atmosphere storage. Food Control 15, 307-313.

Baugerod, H., 1980. Atmosphere control in controlled atmosphere storage rooms by means of controlled diffusion through air-filled channels. Acta Horticulture 116, 179-185.

Fonseca, S.C., Oliveira, F.A.R., Brecht, J.K., 2002. Modelling respiration rate of fresh fruits and vegetables for modified atmosphere packages. Journal of Food Engineering 52, 99-119.

Helga, A., Peter, P., Bernhard, B., Angelika, K., Rolf, K., 1999. Sensory analysis and instrumental measurements of short-term stored tomatoes (Lycopersicon esculentm Mill). Postharvest Biology and Technology 15, 323-334.

Helyes, L., Lugasi, A., Peli, E., Pek, Z., 2011. Effect of elevated $\mathrm{CO}_{2}$ on lycopene content of tomato fruits. Acta Aliment 40(1), 80-86.

Javanmardi, J., Kubota, C., 2006. Variation of lycopene, antioxidants activity, total soluble solids and weight 
loss of tomato during postharvest storage. Postharvest Biology and Technology 41(2), 151-155.

Kader, A.A., Zagory, D., Kerbel, E.L., 1989. Modified atmosphere packaging of fruits and vegetables. CRC Critical Review in Food Science and Nutrition 28, 1-30.

Klieber, A., Ratanachinakorn, B., Simons, D.H., 1996. Effects of low oxygen and high carbon dioxide on tomato cultivar (Bermuda) fruit physiology and composition. Horticulture Science 65, 251-261.

Koca, R.W., Hellickson, M.L., Chen, P.M., 1993. Mass transfer from "d" Anju pears in controlled atmosphere storage. Transaction of the American Society of Agricultural Engineers 36(3), 821-829.

Kudachikar, V.B., Kulkarni, S.G., Prakash, M.N.K., 2011. Effect of modified atmosphere packaging on quality and shelf life of 'Robusta' banana (Musa sp.) stored at low temperature. Journal of Food Science Technology 48(3), 319-324.

Mahajan, P.V., Goswami, T.K., 2001. Enzyme kinetics based modeling of respiration rate for apple. Journal of Agricultural Engineering Research 79(4), 399-406.

Majidi, H., Minaei, S., Almassi, M., Mostofi, Y., 2014. Tomato quality in controlled atmosphere storage, modified atmosphere packaging and cold storage. Journal of Food Science and Technology 51(9), 2155-2161.

McGuire, R.G., 1992. Reporting of objective colour measurements. Horticulture Science 27, 1254-1255.

Moneruzzaman, K.M., Hossain, A.B.M.S., Sani, W., Saifuddin, M., 2008. Effect of stages of maturity and ripening conditions on the physical characteristics of tomato. American Journal of Biochemical and Biotechnology 4, 329-335.

Pila, N., Gol, N.B., Ramanarao, T.V., 2010. Effect of post harvest treatments on physico-chemical characteristics and shelf life of tomato (Lycopersicon esculentum Mill) fruits during storage. American-Eurasian Journal of Agriculture and Environmental Science 9(5), 470-479.

Ramayya, N., Niranjan, K., Duncan, E., 2012. Effect of modified atmosphere packaging on quality of alphonso mangoes. Journal of Food Science and Technology 49(6), 721-728.
Ranganna, S., 1986. Handbook of Analysis and Quality Control for Fruit and Vegetable Products ( $2^{\text {nd }}$ Edn.). Tata McGrawHill Publishing Co. Ltd. New Delhi, 1-104.

Ratti, C., Rabie, H.R., Raghavan, G.S.V., 1998. Modelling modified atmosphere storage of fresh cauliflower using diffusion channels. Journal of Agricultural Engineering Research 69, 343-350.

Sammi, S., Masud, T., 2007. Effect of different packaging systems on storage life and quality of tomato (Lycopersicon esculentum) during different ripening stages. Internet Journal of Food Safety 9, 37-44

Sozzi, G.O., Trinchero, G.D., Fraschina, A.A., 1999. Controlled atmosphere storage of tomato fruit: low oxygen or elevated carbon dioxide levels alter galactosidase activity and inhibit exogenous ethylene action. Journal of the Science of Food and Agriculture 79, 1065-1070.

Stewart, O.J., Raghavan, G.S.V., Goldena, K.D., Gariepy, Y., 2005. MA storage of cavendish bananas using silicone membrane and diffusion channel systems. Postharvest Biology and Technology 35, 309-317.

Tasdelen, O., Bayindirli, L., 1998. Controlled atmosphere storage and edible coating effects on storage life and quality of tomato. Journal of Food Processing and Preservation 22, 303-320.

Vunnam, R., Hussain, A., Nair, G., Bandla, R., Gariepy, Y., Donnelly, D.J., Kubow, S., Raghavan, G.S.V., 2014. Physico-chemical changes in tomato with modified atmosphere storage and UV treatment. Journal of Food Science and Technology 51(9), 2106-2112.

Wrzodak, A., Adamicki, F., 2007. Effect of temperature and controlled atmosphere on the storage of fruit from long life tomatoes. Vegetable Crop Research Bulletin 67, 177-186.

Yang, C.C., Brennan, P., Chinnan, M.S., Shewfelt, R.L., 1987. Characterization of tomatoes ripening process as influenced by individual seal-packaging and temperature. Journal of Food Quality 10, 21-33.

Zagory, D., Kader, A.A., 1988. Modified atmosphere packaging of fresh produce. Food Technology 42(9), 70-77. 